九州大学学術情報リポジトリ

Kyushu University Institutional Repository

\title{
歯周組織創傷治癒過程におけるGDNFおよびシュワン 細胞の機能について
}

糸山，知宏

http://hdl. handle. net/2324/4110459

出版情報: Kyushu University，2020，博士（歯学），課程博士 バージョン：

権利関係: Public access to the fulltext file is restricted for unavoidable reason (2) 
氏 名: 系山 知宏

論 文名 : Possible function of GDNF and Schwann cells in wound healing of periodontal tissue （歯周組織創傷治癒過程におけるGDNFおよびシュワン細胞の機能について）

区 分 : 甲

$$
\text { 論 文 内 容 の 要 旨 }
$$

\section{Objective}

The purpose of this study was to evaluate the function of Schwann cells in wound healing of periodontal tissue.

\section{Background}

In our previous study, glial cell line-derived neurotrophic factor (GDNF) promoted the migration of human periodontal ligament (PDL) cells and that GDNF expression increased in wounded periodontal tissue. GDNF reportedly induces the migration of Schwann cell precursors. Schwann cells play a crucial role in the regeneration of peripheral tissues, including bone tissue. However, the role of Schwann cells on periodontal tissue regeneration remains unclear.

Methods

A transwell assay and a WST-1 (water-soluble tetrazolium compound-1) proliferation assay were used to determine whether GDNF promotes the migration and proliferation of Schwann cells, respectively. Quantitative RT-PCR and Alizarin Red S staining were performed to examine the effect of these cells on the differentiation of human preosteoblast (Saos2 cells) using conditioned medium from YST-1 (YST-1-CM). Western blotting analysis was performed to determine whether YST-1-CM activates ERK signaling pathway in Saos 2 cells. The expression of Schwann cell markers, S100 calcium-binding protein B (S100-B) and growth associated protein 43 (GAP-43), was determined in normal and wounded periodontal tissue by immunofluorescent staining.

Results

Glial cell line-derived neurotrophic factor promoted the migration of YST-1 cells but did not affect the proliferation of YST-1 cells. Saos2 cells cultured with YST-1-CM increased the expression of osteoblastic markers and mineralization. YST-1-CM also induced phosphorylation of ERK1/2 in Saos2 cells. The number of S100-B-immunoreactive cells which also expressed GAP-43 was increased in rat wounded periodontal tissue during healing process.

Conclusion

The accumulation of Schwann cells in wounded periodontal tissue suggests that they play a significant role in wound healing of this tissue, especially alveolar bone tissue. 